\title{
Multicriteria assessment of selected types of ceilings
}

\author{
Julia Nowak $^{1, *}$, and Edyta Plebankiewicz ${ }^{1}$ \\ ${ }^{1}$ Cracow University of Technology, Faculty of Civil Engineering, Warszawska 24, 31-155 Kraków, \\ Poland
}

\begin{abstract}
The paper compares three systems of the rib-and-slab ceiling: Vector, Rector and Teriva. The following comparison criteria were selected: the tare weight of ceiling beams, execution time, slab faulting, sound insulation, thermal insulation and aesthetics of the lower surface. The results of the multicriteria comparative analysis clearly indicated the advantage of the Vector ceiling, assuming the same weights for all criteria taken into account.
\end{abstract}

\section{Introduction}

The basic function of the ceiling is to transfer the load to the walls, and subsequently to the foundations of the building. The ceilings bear their own weight, service loads and load of partition walls. They stiffen the walls of the building and separate storeys. Moreover, they function as acoustic and thermal barriers between storeys. In the event of fire, the ceiling prevents the fire from spreading between storeys .

One of the most widespread, especially in housing construction, are rib-and-slab ceilings. These are the ceilings indicating prefabricated beams as load-bearing elements with spacing between centres not exceeding $90 \mathrm{~cm} \mathrm{[1].} \mathrm{As} \mathrm{a} \mathrm{rule,} \mathrm{beams} \mathrm{are}$ stretched towards a smaller span, leaning them on the walls of the building and buntlines. Supplementary elements located between the beams include, e.g.: ceramic blocks, light expanded clay blocks, gravel concrete bricks, light concrete bricks, as well as styrofoam or gypsum moldings. The upper part of the ceiling is a concrete overlay poured on the construction site.

The paper briefly describes and compares three popular rib-and-slab ceiling systems: Vector, Rector and Teriva. The analysis points out the most attractive solutions out of a total number of three.

\footnotetext{
*Corresponding author: j.nowak96@gmail.com
} 


\section{Ceiling systems}

\subsection{The Teriva ceiling}

Rib-and-slab ceilings the Teriva are one of the longest and most popular ceilings in housing construction, especially single-family buildings. The Teriva involves ribs in the form of truss beams, its reinforcement is concreted and, typically, light expanded clay aggregate (LECA) block or autoclaved cellular concrete block. In the case of the ceiling span of over $4.5 \mathrm{~m}$, partition gilts have to be constructed, laid transversally to the ceiling ribs. Several variants of Teriva are available on the market, variable due to e.g. load capacity, spacing of beams or spread.

The Teriva ceilings are slightly easier to construct than, for example, monolithic ceilings. The low weight of the ceiling elements (hollow blocks or beams with reinforcement) means that they can be arranged by hand. The popularity of Teriva acts positively on impact on its availability.

This kind of ceiling is practically impossible to construct with irregular, complex projects. They are also susceptible to slab faulting, their sound insulation is much worse than that of the majority of ceiling solutions [2].

\subsection{The Vector ceiling}

The Vector ceiling is a relatively new type of ceiling, as it appeared on the Polish market in 2015. The Vector is a composite beam-and-block ceiling. The Vector ceilings consist of panels $4 \mathrm{~cm}$ high and $60 \mathrm{~cm}$ wide. In addition a Vector ceiling is reinforced by a centrally embedded steel truss. Due to the applied truss, the installation of panels on the construction site is easier. Moreover, the trusses are covered with a layer of concrete overlay, thus strengthening the connection with the panels. An additional connection between the layers is strengthened with a bonding layer, which also performs a waterproof function.

The undeniable benefits of this ceiling system are: short assembly time, as well as high load capacity and sound insulation parameters. The additional advantages of this system include no need for an individual project for each room [3-6].

\subsection{The Rector ceiling}

The Rector ceilings have been available on the Polish market for over 10 years. They involve prefabricated prestressed RS beams in several variants, differing in: section height, number and location of the prestressing strands and stiffening with a space truss. They are made of concrete and prestressing steel of high strength parameters (C 50/60 concrete, steel grade $2060 \mathrm{MPa}$ ), thus ensuring high strength and quality of the ceilings designed. The main prestressing reinforcement are strands of high strength steel strings.

The Rector ceilings are distinguished by a combination of prefabrication and advantages resulting from the compression of concrete, which ensure: greater durability, high flexibility of the systems applied (from 16 to over $30 \mathrm{~cm}$ of ceiling thickness and ranging from $1 \mathrm{~m}$ to $10 \mathrm{~m}$ of ceiling span), the deflection reduced to a half, no faulting or scratch effect, neither is the usage of distributing ribs necessary $[7,8]$. 


\section{Criteria for comparison of ceilings}

The implementation cost of the analysed ceilings is similar. In order to choose the best solution, it is worth taking into account the technical parameters specific for each of the ceiling systems.

In order to compare the ceiling solutions, the authors decided to choose six criteria, particularly important from the viewpoint of both the contractor and the future user.

The following criteria were selected:

1. The tare weight of the beams $[\mathrm{kg} / \mathrm{mb}]$ - this parameter largely determines, among others, the necessity of using a crane for transporting ceiling elements.

2. Implementation time $[\mathrm{r}-\mathrm{g}]$ - the assembly time was estimated for $100 \mathrm{~m} 2$ of ceiling area with the assumption that the team involves 4 people.

3. Slab faulting - associated with the stiffness of the ceiling - excessive deflection will result in squeaking of the floor and cracking of the plaster on the ceiling of the lower storey.

4. Sound insulation - the ability to suppress noise is essential from the point of view of the comfort of use. In residential buildings, ceilings should have adequate insulation from airborne sounds (conversation, music, etc.) and sound impact (footsteps, furniture being moved, etc.). This feature is particularly important in the case of ceilings parting residential storeys.

5. Thermal insulation - a ceiling is usually an internal partition that divides rooms with low differences in temperature. In the case of flat roofs and structures separating the basement or a non-use attic, the ceiling should meet appropriate thermal insulation requirements. The lower the heat transfer coefficient of the ceiling, the lower the costs associated with thermal insulation.

6. Aesthetics of the lower surface - smooth and even bottom surface of the ceiling minimizes the cost of plastering or general finishing of the lower surface of the ceiling.

\section{Multicriteria comparative analysis}

In order to find the most advantageous and attractive solution of the ceiling, a multicriterial comparative analysis was conducted. Wide applications of multi-criteria tools facilitating decision making in the construction industry were presented, e.g. in [9-13].

The methods of multi-criteria comparative analysis include a class of algorithms that create a scalar denoting a synthetic evaluation index - the so-called "mathematical methods" [11]. The corrected summation index is the most frequently used discrete multicriteria method [13]. The application of the synthetic evaluation indices requires a division of the evaluation criteria into stimulants which are positively correlated with the dependent variable, and negatively correlated destimulants.

In order to perform the comparison and evaluation of the variants, the chosen evaluation variants of the criteria should be given dimensionless quantities, to perform both quantitative and qualitative comparison.

The procedure involves three steps:

- determining the corrected values of criteria evaluations for individual variants (stimulant, destimulant),

- determining the coded values of criteria evaluations for individual variants,

- determining the corrected a synthetic evaluation index.

Table 1 presents description of criteria applied in the analysis. 
Table 1. Description of criteria using in the analysis.

\begin{tabular}{|c|c|c|c|c|c|c|}
\hline \multirow{4}{*}{ Variants } & \multicolumn{6}{|c|}{ Criteria } \\
\cline { 2 - 7 } & $\begin{array}{c}\text { The tare } \\
\text { weight of } \\
\text { the beams } \\
{[\mathrm{kg} / \mathrm{mb}]}\end{array}$ & $\begin{array}{c}\text { Implementati } \\
\text { on time } \\
{[\mathrm{r}-\mathrm{g}]}\end{array}$ & $\begin{array}{c}\text { Thermal } \\
\text { insulation } \\
{[\mathrm{W} / \mathrm{m} 2 \mathrm{~K}]}\end{array}$ & $\begin{array}{c}\text { Slab } \\
\text { faulting } \\
\text { [points 1-5] }\end{array}$ & $\begin{array}{c}\text { Sound } \\
\text { insulation } \\
{[\mathrm{dB}]}\end{array}$ & $\begin{array}{c}\text { Aesthetics } \\
\text { of the lower } \\
\text { surface } \\
\text { [points 1-5] }\end{array}$ \\
\cline { 2 - 8 } & $\mathrm{K} 1$ & $\mathrm{~K} 2$ & $\mathrm{~K} 3$ & $\mathrm{~K} 4$ & $\mathrm{~K} 5$ & K6 \\
\hline Teriva & 20 & 24 & 0,3 & 2 & 43,3 & 2 \\
\hline Vector & 70 & 11 & 0,3 & 5 & 61,2 & 5 \\
\hline Rector & 16 & 13,5 & 0,43 & 5 & 47,5 & 2 \\
\hline
\end{tabular}

Once the criteria were tentatively defined, they were assigned specific values and to subsequently break down into classes. Subsequently, four methods of coding were performed - standardization; normalization; Neuman-Morgenstern method and Pattern method.

\section{Standardization}

The measure of the $i$-th variant according to the $j$-th criterion:

- for stimulants:

$$
z_{i j}=\frac{x_{i j}-\overline{x_{j}}}{s_{j}}
$$

where:

$x_{i j} \quad$ the value of criteria evaluation

$\bar{x}_{j} \quad$ arithmetic mean

$s_{j} \quad$ standard deviation

- for destimulants:

$$
z_{i j}=(-1) \cdot \frac{x_{i j}-\overline{x_{j}}}{s_{j}}
$$

The standarization method coding result are present in table 2 .

Table 2. Results of coding by the standardization method.

\begin{tabular}{|c|c|c|c|c|c|c|}
\hline \multirow{3}{*}{ Variants } & \multicolumn{5}{|c|}{ Criteria } \\
\cline { 2 - 7 } & \multicolumn{3}{|c|}{ Stimulants } & \multicolumn{3}{c|}{ Destimulants } \\
\cline { 2 - 7 } & \multicolumn{3}{|c|}{ Value $\boldsymbol{z}_{i j}$} & K6 $\boldsymbol{z}_{\boldsymbol{i}}$ \\
\cline { 2 - 7 } & $\mathbf{K 4}$ & $-0,0836$ & $-1,2247$ & 0,0060 & $-1,6872$ & 0,0919 \\
\hline 1 & $-2,4495$ & 0,1196 & 2,4495 & $-0,0136$ & 1,1128 & 0,0919 \\
\hline 2 & 1,2247 & $-0,0360$ & $-1,2247$ & 0,0076 & 0,5744 & $-0,1838$ \\
\hline 3 & 1,2247 & \multicolumn{3}{c}{} & \\
\hline
\end{tabular}

\section{Normalization}

The measure of the $i$-th variant according to the $j$-th criterion:

- for stimulants:

where:

$$
z_{i j}=\frac{x_{i j}}{x_{j \max }}
$$

$x_{j} \max \quad$ maximum value of the measure of weights according to $\mathrm{j}$-th criterion 
- for destimulants:

$$
z_{i j}=\frac{x_{i j^{\prime}}}{x_{j \max }}
$$

where:

$x_{i j}$

reducing descending values to increasing ones (maximizing):

$$
x_{i j}{ }^{\prime}=\frac{1}{x_{i j}}
$$

$x_{j \max } \quad$ maximum value of the measure of weights according to $\mathrm{j}$-th criterion after maximizing.

The normalization method coding results are present in table 3.

Table 3. Results of coding by the normalization method.

\begin{tabular}{|c|c|c|c|c|c|c|}
\hline \multirow{3}{*}{ Variants } & \multicolumn{5}{|c|}{ Criteria } \\
\cline { 2 - 7 } & \multicolumn{3}{|c|}{ Stimulants } & \multicolumn{3}{c|}{ Destimulants } \\
\cline { 2 - 7 } & \multicolumn{3}{|c|}{ Value zij } & Kalue zij \\
\cline { 2 - 7 } & K4 & K5 & K6 & K2 & K3 \\
\hline 1 & 0,4000 & 0,7075 & 0,4000 & 0,8000 & 0,4583 & 1,0000 \\
\hline 2 & 1,0000 & 1,0000 & 1,0000 & 0,2286 & 1,0000 & 1,0000 \\
\hline 3 & 1,0000 & 0,7761 & 0,4000 & 1,0000 & 0,8148 & 0,6977 \\
\hline
\end{tabular}

\section{Neumana - Morgensterna}

The measure of the $i$-th variant according to the $j$-th criterion:

- for stimulants:

$$
z_{i j}=\frac{x_{i j}-x_{j \min }}{x_{j \max }-x_{j \min }}
$$

- for destimulants:

$$
z_{i j}=\frac{x_{j \max }-x_{i j}}{x_{j \max }-x_{j \min }}
$$

Results of coding by the Neumana - Morgensterna method are present in table 4 .

Table 4. Results of coding by the Neumana-Morgensterna method.

\begin{tabular}{|c|c|c|c|c|c|c|}
\hline \multirow{3}{*}{ Variants } & \multicolumn{5}{|c|}{ Criteria } \\
\cline { 2 - 7 } & \multicolumn{3}{|c|}{ Stimulants } & \multicolumn{3}{c|}{ Destimulants } \\
\cline { 2 - 7 } & \multicolumn{3}{|c|}{ Value zij } & \multicolumn{3}{c|}{ Kalue zij } \\
\cline { 2 - 7 } & K4 & K5 & K6 & K1 & K3 \\
\hline 1 & 0,0000 & 0,0000 & 0,0000 & 0,9259 & 0,0000 & 1,0000 \\
\hline 2 & 1,0000 & 1,0000 & 1,0000 & 0,0000 & 1,0000 & 1,0000 \\
\hline 3 & 1,0000 & 0,2346 & 0,0000 & 1,0000 & 0,8077 & 0,0000 \\
\hline
\end{tabular}

The Pattern coding was also performed, consisting of replacing the partial measure by its quotient with the sum of measures of all variants according to the given criterion.

The measure of the $i$-th variant according to the $j$-th criterion:

- for stimulants:

$$
z_{i j}=\frac{x_{i j}}{\sum_{i=1}^{n} x_{i j}}
$$


- for destimulants:

$$
z_{i j}=\frac{x_{i j^{\prime}}}{\sum_{i=1}^{n} x_{i j^{\prime}}}
$$

The Pattern method coding results are present in table 5.

Table 5. Results of coding by the Pattern method.

\begin{tabular}{|c|c|c|c|c|c|c|}
\hline \multirow{3}{*}{ Variants } & \multicolumn{5}{|c|}{ Criteria } \\
\cline { 2 - 7 } & \multicolumn{3}{|c|}{ Stimulants } & \multicolumn{3}{c|}{ Destimulants } \\
\cline { 2 - 7 } & \multicolumn{3}{|c|}{ Value zij } & Kalue zij \\
\cline { 2 - 7 } & K4 & K5 & K6 & K1 & K3 \\
\hline 1 & 0,1667 & 0,2849 & 0,2222 & 0,3944 & 0,2016 & 0,3661 \\
\hline 2 & 0,4167 & 0,4026 & 0,5556 & 0,1127 & 0,4399 & 0,3661 \\
\hline 3 & 0,4167 & 0,3125 & 0,2222 & 0,4930 & 0,3585 & 0,2679 \\
\hline
\end{tabular}

The next step was a synthetic evaluation of the variant solutions. Three different indicators were selected for a more accurate analysis:

- Multiplication indicator - which is the product of the ratings for a given variant of all criteria;

- Summation indicator - the sum of all evaluations;

- Additive indicator - the sum of the scores is divided by the number of criteria.

- Results of analysis are presented in Table 6, Table 7, Table 8 and Table 9.

Table 6. Results of analysis for standardization coding.

\begin{tabular}{|c|c|c|c|}
\hline Variants & Summation indicator & Additive indicator & ORDER \\
\hline 1 & $-5,3471$ & $-0,8912$ & III \\
\hline 2 & 4,9850 & 0,8308 & I \\
\hline 3 & 0,3622 & 0,0604 & II \\
\hline
\end{tabular}

Table 7. Results of analysis for normalization coding.

\begin{tabular}{|c|c|c|c|c|}
\hline Variants & $\begin{array}{c}\text { Multiplication } \\
\text { indicator }\end{array}$ & $\begin{array}{c}\text { Summation } \\
\text { indicator }\end{array}$ & $\begin{array}{c}\text { Additive } \\
\text { indicator }\end{array}$ & ORDER \\
\hline 1 & 0,0415 & 3,7658 & 0,6276 & III \\
\hline 2 & 0,2286 & 5,2286 & 0,8714 & I \\
\hline 3 & 0,1765 & 4,6886 & 0,7814 & II \\
\hline
\end{tabular}

Table 8. Results of analysis for N-M coding.

\begin{tabular}{|c|c|c|c|}
\hline Variants & Summation indicator & Additive indicator & ORDER \\
\hline 1 & 1,9259 & 0,3210 & III \\
\hline 2 & 5,0000 & 0,8333 & I \\
\hline 3 & 3,0423 & 0,5071 & II \\
\hline
\end{tabular}

Table 9. Results of analysis for normalization coding.

\begin{tabular}{|c|c|c|c|c|}
\hline Variants & $\begin{array}{c}\text { Multiplication } \\
\text { indicator }\end{array}$ & $\begin{array}{c}\text { Summation } \\
\text { indicator }\end{array}$ & $\begin{array}{c}\text { Additive } \\
\text { indicator }\end{array}$ & ORDER \\
\hline 1 & 0,0003 & 1,6358 & 0,2726 & III \\
\hline 2 & 0,0017 & 2,2935 & 0,3822 & I \\
\hline 3 & 0,0014 & 2,0707 & 0,3451 & II \\
\hline
\end{tabular}




\section{Summary}

The paper compares three popular systems of rib-and-slab ceilings. Taking into account the similar cost of the solutions, the technical parameters characterizing the selected floor systems were adopted for the analysis. It was also assumed that all the adopted parameters were of the same importance for the decision maker. With such assumptions, the methods used for the multi-criteria analysis indicated unambiguously the advantage of the Vector ceiling over the other solutions. Yet it should be remembered that the investor's preferences can change the ranking of the solutions obtained. For example, the need to use a crane may, in some cases, eliminate the choice of the Vector ceiling.

\section{References}

1. http://www.stropy.pl/ (access date: 10. Jan. 2018)

2. http://www.stropex.com.pl/ (access date: 10. Jan. 2018)

3. http://strop-vector.eu/strop-vector/ (access date: 10. Jan. 2018)

4. http://www.fabrykastropow.pl/zespolony-strop-gestozebrowy-vector (access date: 10 . Jan. 2018)

5. http://stropvector.pl/ (access date: 10. Jan. 2018)

6. http://www.konbet.com.pl/ (access date: 10. Jan. 2018)

7. http://www.rector.pl/ (access date: 10. Jan. 2018)

8. https://rector.informatorbudownictwa.pl/ (access date: 10. Jan. 2018)

9. R. T. Marler, J. S. Arora, Struct Multidiscipl Optim, 26(6), 369-395, (2004)

10. M. Dytczak, Wybrane metody rozwiazywania wielokryterialnych problemów decyzyjnych w budownictwie (Politechnika Opolska, Opole, 2010)

11. J. Szwabowski, J. Deszcz, Metody wielokryterialnej analizy porównawczej (Politechnika Śląska, Gliwice, 2001)

12. A. Leśniak, B. Szewczyk, Tech Trans, 28, 4-B, 185-190, (2015)

13. T. Trzaskalik, Zesz. Nauk. PŚl, seria : Organizacja i Zarządzanie 74, 239-263, (2014) 